\title{
THEATRE ORGANIZATION SYSTEM IN POLAND SINCE 1980s
}

\begin{abstract}
The system of theatre organization in Poland should have basically changed after the political transformation in 1989. This year marked the break up with the central leadership of the Communist Party, followed by introduction of the Act on organizing and conducting cultural activities in 1991 . Although the new system of public theatres attributed to appropriate levels of local government seemed fair, it was also deemed quite rigid. After more than twenty-five years, there are several elements that are more changeable than sustainable.
\end{abstract}

SŁOWA KLUCZE: system organizacji teatrów, teatr w Polsce, polityka kulturalna

KEY WORDS: theatre organization system, theatre in Poland, culture policy

Despite the common tendency to create various local development strategies for regions, cities and cultural sectors, public theatres' organisation system remains resistant to change. This resistance means that during its way from both administrative and legislative reforms the changeability cannot achieve the level of sustainability, construed as the ability to react to social and economic changes, which is reflected not only in artistic activities, but also in the proper systemic transformations.

According to the Central Statistical Office (GUS - Główny Urząd Statystyczny), there are only 170 artistic organisations ${ }^{1}$ in Poland (theatres and music institutions), which have their own permanent ensembles. This data, however, is not particularly applicable to theatre market statistics as theatres' performance is determined by artistic season that lasts from the $1^{\text {st }}$ of September to the $31^{\text {st }}$ of August. I will therefore refer to other records, collected by the Theatre Institute, which conducts analyses of subsequent theatre seasons in Poland, designed to reflect the unique nature of this sector.

${ }^{1}$ GUS figures are provided on the basis of the annual calendar. In 2013 there were 170 institutions, in 2014 - 171. See: Kultura 2014, Warszawa 2015, p. 88. 
During the 2013/2014 season, artistic activity of 778 theatres ${ }^{2}$ of different performance and organizational status was registered. These include 89 drama theatres, 68 puppet theatres, 38 musical theatres, 93 dance theatres and, under „others” category, as many as 490 different ensembles. Although the organizational structure is diversified, from the standpoint of modern economy in the public sector we can distinguish 118 theatres, 162 in the private one and 184 in the non-profit sector. When it comes to records concerning municipal theatres, there are 122 such institutions, however, due to lack of sufficient information (number of premieres, number of plays in the repertoire, attendance etc.) we cannot treat them as strictly as in the case of public theatres.

Table 1. Classification of theatres with regard to the organizing authority

\begin{tabular}{|l|c|c|c|}
\hline & $\mathbf{2 0 0 9 / 2 0 1 0}$ & $\mathbf{2 0 1 1} / \mathbf{2 0 1 2}$ & $\mathbf{2 0 1 3 / 2 0 1 4}$ \\
\hline National & 3 & 3 & 3 \\
\hline Marshal & 44 & 42 & 43 \\
\hline City & 71 & 70 & 11 \\
\hline County & 2 & 1 & 162 \\
\hline Private & 122 & 136 & 127 \\
\hline Associations & 95 & 110 & 57 \\
\hline Foundations & 26 & 39 & 111 \\
\hline Part of city cultural institutions & 96 & 98 & 1 \\
\hline
\end{tabular}

As far as 118 public theatres are concerned (season 2013/2014), it should be emphasised that majority of them, which in total amounts to $97 \%$ of these institutions, are maintained by local government organisations - theatres which are organized by Marshal Offices, Municipal Offices or Poviat Offices.

Recent years have seen an increase in the number of private theatres. Essentially, the statistics show that their activities are outstandingly diversified which is proved by the fact that as many as 103 theatres define their actions as different than those listed in the above-mentioned scheme of different performance types. I will explore the nature of theatres existing in the non-profit sector further in this paper. I would like to emphasise here, however, that it is the only sector developing or changing its own structures so as to establish new solutions and foster cross-sectorial cooperation.

In recent years, there has been a continuous tendency indicating $2 \%$ increase in attendance in Polish theatres. During the 2013/2014 season, 5928610 spectators

2 See: Teatr w Polsce 2015, dokumentacja sezonu 2013/2014, Instytut Teatralny im. Zbigniewa Raszewskiego, Warszawa 2016. 
went to theatres, which constitutes about $15 \%$ of general population, and this turnout should be treated as a sign of a positive trend.

The most fundamental changes in Polish theatre organizational system were introduced after 1989, at a time that was not only significant for cultural policy, but for the whole country. It was the period of Polish political system transformation that heralded the end of one-party system of the People's Republic of Poland, as well as the collapse of the centrally planned economy. What was particularly essential for culture was the end of political censorship. In order to shed some light on the reforms adopted in the cultural policy and the theatre organizational system, I shall summarize the circumstances that arose at the end of 1980s. This brief introduction into the cultural policy of the People's Republic of Poland era aims at showing the organizational, formal and financial situation of theatres after the political transformation.

Before the systemic transformation, cultural policy was determined by the absence of freedom of speech and a monopoly of power of PZPR (Polish United Workers' Party - a communist party). Consequently, cultural policy at the time of PRL (People's Republic of Poland) existed in various forms, all of which were supposed to allow the authorities to control the cultural sector and thus they were immensely manipulative. This was mainly due to a strong correlation between culture and other sectors and triggered many inconveniences to artists and directors, such as Tadeusz Kantor or Jerzy Grotowski ${ }^{3}$. It ought to be noticed, however, that Polish theatre found its own immanent means of artistic expression at that time, using metaphor to oppose the censorship, which resulted in many important performances. It was during the People's Republic of Poland era that Polish theatre earned its reputation abroad. Owing to the above-mentioned artists (among others), it marked its individual character, style and aesthetics - which remained the trademark of Polish theatre to this day ${ }^{4}$.

Foreign policy, especially that of the Soviet Union, but also domestic policy aimed at blurring class divisions and simplifying social structure, played an important role in the shaping of theatre system and the culture of the time. . It was a common practice to use culture as a means of pressure, political propaganda, or as a tool of executing penalty or, on the contrary, awarding a prize. Significantly, the culture that existed in such a controlled system was virtually independent from society's economic status and the state budgetary resources. Such conditions have influenced both art creators and recipients of culture who were brought up at the time of PRL.

During the reign of People's Republic of Poland the state theatres (in 1988 there were 111 of them, during the 1987/88 season they performed over 33.000 plays) were under the authority and guidance of the central government - the Ministry of Culture. In this regard, the theatres were financed by the Ministry and thus had to comply with central directives concerning the repertoire. For instance, there was a list with

${ }^{3}$ K. Prykowska-Michalak, Years of compromises and political servility - Polish artist during Cold War [in:] Ch. Balme, B. Szymanski-Duell (Eds.), Theatre, Globalization and the Cold War, London 2017, p. 189-205.

${ }^{4}$ K. Prykowska-Michalak Die Buehne als transkultureller Begegnungs- und Vermittlungsraum. Berliner ,, Teatr Kreatur” (1988-2003) von Andrej/Andrzej Woron(iec) [in:] M. Kopij-Weiss, M. Zielińska (Eds.), Transfer und Vergleich nach dem Cross-Cultural-Turn, Leipzig 2015, p. 383-399. 
preferred plays to perform, the directors of more significant theatres were chosen by the highest dignitaries of the Polish United Workers Party $\left(K_{C}\right.$ PZPR $\left.{ }^{5}\right)$ or on the lower party structures. Most of the theatres, however, had their own artistic programmes.

Since promoting culture among workers was obligatory and the inexpensive tickets were distributed in the workplaces, in 1988 over 10 million spectators visited public theatres.

One should also pay attention to underground art performances that were organized by student theatres. These groups existed and developed outside the mainstream public theatre system, the majority of them offered authorial repertoires with performances aimed to question and criticise the central authorities.

The above-described theatre organization system and centrally planned cultural policy remained unchanged for over 40 years. After 1989 cultural institutions including theatres - as well as other areas of everyday life - were struggling to adjust to the new realities of market economy.

The systemic transformation triggered many changes in the way culture sector was organized and thus it also influenced the theatres. Regulatory mechanisms were introduced to control public orders and finances. Furthermore, there was a substantial change in public administration competencies with regards to organizing and financing cultural institutions. Essentially, numerous new solutions were introduced in the area of financing, organizing and management of cultural institutions.

Among the above-mentioned transitions, the most significant one was associated with the gradual process of decentralization that involved several stages.

In September 1989, the position of the Ministry of Culture in the first non-Communist government was assumed by Izabella Cywińska (theatres' manager), who declared a gradual move away from subsidizing all public theatres from the state budget. This initiative came as a result of reinstating the institution of local government and consequently transferring the competencies that were previously in the scope of central authorities.

By virtue of the act of $1990^{6}$, urban districts started to be responsible for the governance of certain cultural institutions - mostly minor organisations - like local culture centres, libraries etc. In general, theatres remained a government administration responsibility, however not all of them were maintained in this way since appropriate system was developed to categorise theatres and provide only a few of them with total subventions (they were chosen with regards to artistic and localization aspects). Remaining theatres could only rely on partial grants from the state.

An attempt to categorise theatres, often performed in an inevitably inaccurate manner, is typical of reforms introduced in the Polish public theatres organisation system. In fact, between 1990 and 1999, various assemblies tried to create a list of both - theatres that would be financed at the central level and those receiving subventions from local authorities. The current theatre organisation system is based upon division

5 The Central Committee of the Polish United Workers' Party.

6 The act on the division of competences between authorities on different levels of government, "Journal of Laws" 1990, No. 34. 
established in 1999, which became applicable after foundation of the new administrative order which has not undergone any major changes since then. However, taking into account the dynamics of external circumstances that determine the theatres, the development of art and society, demographic changes and many other factors, the following question arises: Are the criteria introduced at the end of the 1990s that allowed the choice of national theatres and so-called Marshal theatres and the municipal ones ${ }^{7}$ inviolable? Should not the way towards sustainability go through the evolution of institutions in the public sector? And how would that be possible if this sector is defined by the same act since 1991 and, despite minor amendments, it has not been improved? In fact, the introduction of the Act of 25 October 1991 on organizing and conducting cultural activity was a bold move. The Act concerned both theatres and other cultural institutions, which were endowed with significant freedom of organising artistic activities, but also made them responsible for their own budgets. The new act allows local governments to establish and transform cultural institutions; it also gives the possibility to pass national institutions to local governments, as well as create and finance joint institutions. Finally, the new law increased the importance of local government administration and thus emphasised its role in the theatre life.

Changes in the organisation system of theatres were made in stages so that once the Act on organising and engaging in cultural activity was introduced, only a few theatres were assigned to local governments. At that time, the main objective was to select institutions to be taken under national care, which meant financing and supervision of the Ministry of Culture. First national institution was the Institute of National Theatre in Warsaw. The next was the Old Theatre in Cracow (Stary Teatr w Krakowie), the dramatic financial situation of which forced the director to close the theatre in the middle of the season. In order to support it, in 1991 the Old Theatre was included on the list of national institutions. Essentially, since the list was completed, it has not been verified to this day.

The first stage of decentralisation of theatre organisation system was concluded with the following result: 15 theatres were assigned to municipal governments, among them were drama theatres (10), two puppet theatres and one Operetta in Warsaw, and also the City Theatre in Gdynia and the Baj Pomorski theatre in Torun, which were the first ones assigned under the authority of the city administration.

The next significant stage of systemic changes in the cultural sector was associated with the project embarked on in 1993 - the "Pilot Program of Public Administration Reform", aimed to ensure agreement with government administration bodies of 46 biggest cities, which had to undertake more responsibility in terms of management and financing of their cultural institutions. For theatres, the pilot program heralded an accelerated systemic decentralisation, which resulted in reducing the number of theatres. As it turned out, the new regulation did not concern all 93 state theatres assigned to the Ministry and by virtue of unknown categorisation a new list was established

7 Theatres, mainly operettas and larger institutions, which are assigned to the self-government of the voivodships, the self-government is directed by the Marshal. 
that excluded certain theatres from the pilot program ${ }^{8}$, which was further extended by the forthcoming government.

Only after passing a new law on changing the scope of certain municipal governments and on urban zones of public services in autumn of 1995, there was a rise in the number of cultural institutions assigned to the local governments. Whereas an amendment to the Act on organizing and conducting cultural activity passed in 1996 introduced the division of cultural institution into two categories: state/national cultural institutions (whose organising authority was the Ministry of Culture or another central government unit or a voivode) and self- governing cultural institutions (maintained by local governments). Furthermore, another classification was created to indicate the degree of state's responsibility in terms of financing these institutions. According to it, national theatres were selected as the ones particularly significant for the development of culture and therefore subsidised directly by the Ministry, whereas the remaining state institutions were assigned to the voivodes. The legislative process of changing the theatre organization system came to an end together with introducing a new decentralisation and competence reform (from the 1st of January, 1999) that enforced creation of 16 new voivodships. This modification was preceded by two acts enacted on the 5th of June, 1998, concerning poviat and voivodships' self-governments. As a result, a new classification of cultural institutions emerged, in which opera houses and significant drama theatres were assigned to voivodships' self-governments, while the rest of theatres were distributed between cities and poviats.

This division, or rather yet another classification, was made without any social or professional consultancy 9 . Some theatre researchers claim that the division was inspired by the German theatre organisation system, where 16 theatres have the status of Staatstheater, which are institutions financed by federal states, and municipal or city theatres called Landes or Stadtheater. The German system has proved to be successful for over 200 years: Staatstheater previously belonged to courts and minor states, their significance is reflected in the prefix "Staat" which means "state" Whereas smaller court theatres located outside of the state capitals were transformed into municipal and city theatres ${ }^{11}$.

The above-discussed example illustrates that these two systems are not easily comparable. Some of them are deeply rooted in the tradition - as it is in Germany - or determined by temporary regulations coming from the political-administrative system.

817 theatres, among others from: Białystok, Bydgoszcz, Gdańsk, Katowice, Koszalin, Gardzienice, Lublin, Łódź, Olsztyn, Opole, Poznań, Szczecin, Toruń, Wrocław, were supposed to be excluded from the pilot program.

9 D. Ilczuk, W. Misiąg, Finansowanie i organizacja kultury w gospodarce rynkowej, Warszawa 2003 , p. 51.

${ }^{10}$ State countries as legal successors of the monarch inherited the responsibility to finance the theatres. Almost all the state capitals have at least one Staatstheater. Many of these theatres are located in historic buildings.

${ }^{11}$ The majority of currently existing city theaters that receive subventions from public funds were founded in the nineteenth century, mostly owned by private persons or bourgeois associations - today we would say that they were created by local civic communities. 
Changes in the theatre organisation were also provoked by internal dynamics of the system. After 1989, apart from state theatres - today the public ones - there was also a tradition of independent theatre that was encouraged by student theatres that existed and developed outside of the established public financing system. After systemic transformation not only did theatres changed their mission, but it also affected their formal and legal status as some of the theatres were assigned to the cities ${ }^{12}$, whereas others remained as independent institutions that finance their activities from subventions obtained from local governments and the Ministry.

Non-public theatres in Poland are the for-profit private institutions existing as business activity. In this regard, commercial law regulates them, particularly the directives from the Act on business activity from of 23 of December 1988. In the 2013/2014 season there were 162 such theatres in Poland.

As I mentioned before, however, the sector that develops in the most dynamic way is the one comprising non-governmental, non-profit organisations (associations or foundations). It is nevertheless important to note that not only independent theatres have the status of non-governmental institutions (as it was before 1989), but it is just one of the possible organisational forms in the cultural sector. Essentially, theatres legally existing as foundations may run strictly commercial activity and invest their profit into new productions, like it is in the case of the Polonia Theatre and the Och-Theatre. Undoubtedly, it makes this sector more flexible and thus able to easily adapt to changing external conditions.

However, the theatres in the non-profit sector are most commonly run by associations whose way of working (the social activity of the members, lack of permanent repertoire) resembles independent student theatres which existed before 1989. Theatres in the third sector are supported in various ways by local governments through numerous project contests for organising theatre season, as it was some years ago in Grudziądz, but they also have the possibility to initiate cooperation based on partnership between public institutions and the NGOs. The most common forms of support here are grant-based projects. In 2008, for example, three-year subventions were implemented that were aimed to enforce the activity of several non-profit theatres in Warsaw. Since 2000, it has been also possible to apply for subventions from the Ministry of Culture that offers a few projects on financing a particular cultural activity. Although these projects are available to institutions from all sectors, the most privileged ones are in fact the non-governmental organisations.

Public theatres, like other cultural institutions that are subject to the Act from 1991, run their self-dependent financial management, which is based on the

12 The Theatre of The Eight Day is one of the most acclaimed Polish theatre groups founded during counterculture student theatre movement from the 1960s. Since 1979 it has functioned as a professional theatre. In autumn of 1990 the theatre was invited by the Prime Minister (Tadeusz Mazowiecki) to come back to Poznań, not as an independent non-governmental organization, but as a municipal institution of culture - public theatre assigned to the City Council of Poznań. In 2004, the Dance Theatre from Kielce also became the municipal institution of culture, before it functioned as an association. In 2005 in Cracow, two new municipal institutions of culture were created: the KTO Theatre and the Łaźnia Nowa Theatre. 
institution's action plan approved by its director with respect to subventions determined by the organizing authority.

According to the directive of art. 9 p. 13 of the Act passed on 27 August 2009, concerning public finances ${ }^{13}$, self-governmental cultural institutions belong to the public finance sector. This entails particular consequences in terms of restrictions concerning spending funds, procedures, planning duties and reporting. The revenue of cultural institutions is treated as public funds, regardless of the ways in which it was acquired.

In 1997 the subvention allocated by the organizing authority to drama theatre accounted for around $75 \%$ of its budget, the 2012 figures present that percentage share decreased significantly to $56,81 \%$. Theatres' own revenue most commonly comes from the sale of tickets and the income obtained from renting a venue. Over the years it accounts for $20 \%$ of the budget, there are also theatres that receive even more than $40 \%$ income (Bagatela Theatre) ${ }^{14}$.

The sponsorship of public cultural institutions is still very rare in Poland; private entrepreneurs support only selected theatre productions as in the case of, for example, the Roma Theatre, or prestigious festivals and other cultural events.

Theatres who are formally organised as self-governmental cultural institutions are allowed to apply for the Ministry of Culture's grant-based projects from which they can obtain funds for their artistic initiative and festivals.

The theatre infrastructure has been recently supported by subventions assigned within the structural funds mainly coming from the European Regional Development Fund planned within the framework of the Regional Operational Programmes, but also within the Operational Programme Infrastructure and Environment. Between 2007-2013, 10 institutions benefited from these funds, among them were, for instance, the Centre for Theatre Practices "Gardzienice", the Podlasie Opera and Philharmonic and the Gdansk Shakespeare Theatre.

The main issue with financing public theatres boils down to the so-called "costs illness", which needs to be finally cured. The researches have proved that the costs of performance production, the remuneration of artists and other theatre employees rise more rapidly than the total costs of national economy (calculated by the inflation-indexed bonds). Baumol and Bowen came to the conclusion that the culprit of such situation lies in the lack of innovation in the field of theatre productions, which further forbids the introduction of cost-saving economic strategies. In the meantime the studies conducted by other economists, for instance Douglas North (Economic Performance Through Time), have shown that it is the growth of the institutions (originally those informal that with time transformed into the formal, not always profitable ones) that has provoked the substantial development of the Western civilization, construed as a region with the highest quality of life.

13 "Journal of Laws" No. 157, item 1240, as amended.

${ }^{14}$ See: J. Szulborska-Łukaszewicz, Miejsce teatru w polityce kulturalnej państwa i polskich samorządów (teatry krakowskie - studium przypadków) [w:] K. Prykowska-Michalak (Ed.), Systemy organizacji teatrów w Europie, Warszawa 2017, p. 306. 
We should therefore consider, without going to extremes with constant complaining or, on the other hand, creating overdeveloped large modern theatres in small villages (like in Nordic countries), whether this mechanism goes round and allows the sustainability to replace the previous period of changeability?

\section{Bibliography}

Balme Ch., Szymanski-Duell B. (Eds.), Theatre, Globalization and the Cold War, London 2017. Ilczuk D., Misiąg W., Finansowanie i organizacja kultury w gospodarce rynkowej, Warszawa 2003. Kopij-Weiss M., Zielińska M. (Eds.), Transfer und Vergleich nach dem Cross-Cultural-Turn, Leipzig 2015.

Kultura 2014, Warszawa 2015.

Prykowska-Michalak K. (Ed.), Systemy organizacji teatrów w Europie, Warszawa 2016. Teatr w Polsce 2015, dokumentacja sezonu 2013/2014, Warszawa 2016. 